\title{
Effects of irrigation intervals and organic manure on morphological traits, essential oil content and yield of oregano (Origanum vulgare L.)
}

\author{
FARZAD GERAMI ${ }^{1}$, PARVIZ R. MOGHADDAM ${ }^{1}$, REZA GHORBANI ${ }^{1}$ and ABBAS HASSANI ${ }^{2}$ \\ ${ }^{1}$ Department of Agronomy, Faculty of Agriculture, Ferdowsi University of Mashhad, P.O. Box 91779-8974 Mashhad, Iran \\ ${ }^{2}$ Department of Horticulture, Faculty of Agriculture, Urmia University, P.O. Box 57561-51818 Urmia, Iran
}

Manuscript received on April 25, 2016; accepted for publication on September 20, 2016

\begin{abstract}
In order to evaluate the effect of irrigation intervals and cattle manure levels on morphological traits, essential oil content and yield of oregano, an experiment was conducted at the experimental Farm of the Faculty of Agriculture, Urmia University, Iran. The experimental design was split-plots, arranged in randomized complete blocks with three replications. Main plots including irrigation intervals $(1,2$ and 3 weeks) and four levels of cattle manure at $0,10,20$ and $30 \mathrm{tha}^{-1}$ were allocated to sub plots. Our results showed that increasing irrigation intervals reduced values of all morphological traits except for proportion of stems. Also, values for stems number, plant spread, stem diameter, leaf area, fresh and dry herb yield increased by increasing cattle manure levels. On the other hand, morphological traits not influenced by interaction of treatments except for plant spread and leaf area. The highest essential oil content $(2.07 \%)$ and yield $\left(66.62 \mathrm{~kg} \mathrm{ha}^{-1}\right)$ obtained in highest irrigation intervals and cattle manure levels. Whereas, 1 week irrigation interval without use of cattle manure produce lowest essential oil content (1.55\%). For essential oil yield, the lowest value ( $\left.46.37 \mathrm{~kg} \mathrm{ha}^{-1}\right)$ was found in 2 weeks irrigation interval with application of $20 \mathrm{t}$ ha $^{-1}$ cattle manure.
\end{abstract}

Key words: cattle manure, essential oil, irrigation, Origanum vulgare L., yield.

\section{INTRODUCTION}

Nowadays, due to considerable effects of plants medication and their healthcare properties, in worldwide the consumption of medicinal plants and natural antioxidants are increasing continuously (Hecl and Sustrikova 2006, Liang et al. 2010, Raut and Karuppayil 2014). But, over utilization of medicinal and aromatic plants from natural habitats has damaged plant communication and caused a serious threat to these valuable herbs (Hoareau and

Correspondence to: Parviz Rezvani Moghaddam

E-mail: rezvani@um.ac.ir
Da Silva 1999). For this reason, global approach is to the production of medicinal plants in sustainable farming systems (Valiki et al. 2015).

For cultivation of medicinal and aromatic plants under field conditions, different management practices are require including awareness of ecological properties of plants, time of planting, plant density, nutrient and water requirements (Ozguven et al. 2008, Tabrizi et al. 2011). Among the different environmental constraints, water is one of the most important limiting factors for plant productivity (Bannayan et al. 2008, Laribi et al. 2009). 
Delfine et al. (2005) reported that the average of yield decrease on a world wide scale at more than $25 \%$ due to water deficit. Plant productivity and photosynthesis are adversely affected by water stress due to a series of morphological, physiological, biochemical and molecular changes (Tezara et al. 1999). Water deficit alters plant metabolism and severely affecting ecosystems and agriculture (Tezara et al. 1999, Wang et al. 2001). The optimization of irrigation are important in order to produce optimum fresh herbs and seed yield, because water is a major component of the fresh produce and effects both quantity and quality of crop yield (Jones and Tardien 1998, Ucan et al. 2007). In the case of medicinal plants, water deficit may cause changes in the biomass yield and composition of their essential oils. Effect of water stress on essential oil content and yield, secondary metabolites, morphological and physiological characteristic of different medicinal and aromatic plants has been reported in several studies. In Thymus transcapicus Klokov, increase of irrigation intervals caused significant reduction in dry weight, proportion of stem, leaf and flower in second year (Tabrizi 2011). Tucker and Maciarello (1994) found that water stress has negative effect on biomass and essential oil content in oregano (Origanum vulgare L.). Also, Hassani (2006) revealed that the plant height, stem diameter, number and length of auxiliary shoots, fresh and dry herb yield of Dracocephalum moldavica was declined with decreasing soil water content. In other hand, several study shown positive effect of water deficit on essential oil and alkaloids in medicinal plants (Bettaieb et al. 2009, Gholizadeh et al. 2010). In this respect, Khalid (2006) reported that severe water stress improved essential oil content more than moderate stress. Plant growth of Ocimum americanum L. decreased in response to water deficit, but essential oil and proline contents was increased with increasing water stress (Baeck et al. 2001).
Also, crop production is related to soil fertility. Fertile soil is fundamental resource for higher crop production, which supplies all the essential nutrients to the crop. Therefore, maintenance of soil fertility can be a pre-requisite for long term sustainable crop production (Schroth and Sinclair 2003). Long term use of chemical fertilizers depletes soil organic matter, causes soil degradation and environmental pollution problems (Rao 2001). Organic manures are carbon-based compounds that increase the productivity and improve quality of plants (Leu 2007). They have various benefits over chemical fertilizers. Organic fertilizers are low priced and eco-friendly inputs that have tremendous prospect of supplying nutrients which can reduce the over dependence on chemical fertilizer (Bajeli et al. 2016). The use of organic manure to soil amendments has been associated with desirable soil properties including higher plant available, water holding capacity, cation exchange capacity and lower bulk density as well as can foster beneficial microorganisms (Drinkwater et al. 1995). Previous studies have shown application of organic manures had progressive effects on seed yield, fresh weight, seed essential oil content and yield in Coriandrum sativum L. (Darzi 2012) and Melisa officinalis L. (Santos et al. 2009). Ram and Kumar (1997) found that utilization of organic manure in Mentha piperita L. was most effective in increasing the total biomass and essential oil yield. In other study, Kaplan et al.. (2009) showed that use of organic manure in Salvia officinalis improved fresh herb yield and essential oil content 43 and $41 \%$, respectively.

Oregano (Origanum vulgare L.) belongs to the Lamiaceae family is a perennial herb (Vokou et al. 1993, Spada and Perrino 1996). This plant can be found abundantly on dry, rocky calcareous soils of mountain areas at a wide range of altitude from 0 to $4000 \mathrm{~m}$ (Snogerup 1971) that grows throughout the Mediterranean, Euro-Siberian and Irano-Turanian regions (Aligianis et al. 2001). Essential oil of 
oregano has antimicrobial, antioxidant, cytotoxic and antifungal properties (Adams et al. 1998). Also, this plant is popular culinary herbal crops that commonly used in the agriculture, pharmaceutical and food industry (Aligianis et al. 2001).

Limited information is available about the response of oregano to irrigation and nutrient supply. Therefore, the objective of this research was to investigate the performance of oregano under irrigation intervals and different cattle manure levels.

\section{MATERIALS AND METHODS}

\section{EXPERIMENT SITE}

This study was conducted at the research farm of Agriculture College of Urmia University, Iran (37 32> N latitude and $45^{\circ} 5$, E longitudes) at an elevation of $1320 \mathrm{~m}$ above sea level during 2014 growing season. This site was characterized by semi-arid climate with a mean annual precipitation of $315.3 \mathrm{~mm}$ and average temperature of $13.48^{\circ} \mathrm{C}$. The soil characteristics from the experimental field and organic manure (cattle manure) are given in Table I.

The experimental design was a split-plot randomized complete blocks with three replications in which irrigation intervals $\left(1\left(\mathrm{IR}_{1}\right), 2\left(\mathrm{IR}_{2}\right)\right.$ and 3 $\left(\mathrm{IR}_{3}\right)$ weeks) were allocated in main plots and cattle manure levels $\left(0,10,20\right.$ and $\left.30 \mathrm{tha}^{-1}\right)$ as sub plots.

Seeds of oregano were collected from natural habitat and sown under greenhouse conditions in small pots ( $8.2 \mathrm{~cm}$ height and $7 \mathrm{~cm}$ diameter) in a medium of mixed leaf mold, sand and loamy soil $(1: 2: 3 \mathrm{v} / \mathrm{v})$. Then 70 days old seedling after acclimation ( 5 days) were transferred outdoor in 5
May. They transplanted at 40 and $25 \mathrm{~cm}$ distance between rows and within rows, respectively. Each main plot size was $33.6 \mathrm{~m}^{2}(12 \times 2.8 \mathrm{~m})$ that divided to four sub-plots $(3 \times 2.8 \mathrm{~m})$. The first irrigation was conducted immediately after transplanting. Then two irrigation stages were also applied with intervals of 3 and 6 days for uniform establishment of seedlings.

Different quantities of five years composted cattle manure were broadcasted uniformly and incorporated to the soil four months prior to transplanting. Experimental plots were irrigated up to field capacity $\left(22.5 \% \theta_{\text {fc }}\right)$ with 330 liter in irrigation. Weeds were controlled by hand-hoeing when necessary.

\section{MORPHOLOGICAL MEASUREMENT}

Plant height was measured from the soil surface to the tip of the tallest flowering stem at full flowering stage. For each treatment, measurement of fresh and dry matter weights were evaluated by harvest of five randomly selected plants from the center rows of each plot. Plants were harvested at a height of 5 $\mathrm{cm}$ above ground and immediately weighted (fresh matter weight). After that plants were dried in a dry oven at $65^{\circ} \mathrm{C}$ for $48 \mathrm{~h}$ and re-weighted (dry matter weight). The proportion of leaves, stems and flower were separately determined by weighting of these segments with a digital balance. The fresh and dry herb yield $\left(\mathrm{kg} \mathrm{ha}^{-1}\right)$ was determined by harvesting a $2 \mathrm{~m}^{2}$ area from each plot. The collected plants were immediately weighted (fresh herb yield) by a digital balance, then dried in the shade until it reached a constant weight and weighted (dry herb yield).

TABLE I

Chemical and physical characteristics of the soil and cattle manure used in the field experiment.

\begin{tabular}{|c|c|c|c|c|c|c|c|}
\hline & pH & $\mathrm{OC}(\%)$ & $\mathrm{EC}\left(\mathrm{dS} \mathrm{m^{-1 } )}\right.$ & Total N (\%) & $\mathbf{P}(\mathrm{ppm})$ & K (ppm) & Texture \\
\hline Soil & 7.5 & 0.92 & 0.65 & 0.16 & 12.1 & 338 & Clay-loam \\
\hline Cattle manure & 8.2 & 38.9 & 12.16 & 2.06 & 974 & 13700 & - \\
\hline
\end{tabular}




\section{SEED YIELD AND 1000 SEED WEIGHT}

For each treatment, seed yield of oregano was measured at maturity stage by harvesting a $2 \mathrm{~m}^{2}$ area from center rows of each plot. Then seeds were cleaned and seed yield were determined with digital balance (after drying). Also, for 1000 seed weight, 200 seeds were weighted.

\section{ESSENTIAL OIL CONTENT AND YIELD}

Fresh plants were cut at $5 \mathrm{~cm}$ above ground level at flowering stage from each treatment. Then, they were dried in the shadow for two weeks. Essential oils from shade dried parts of oregano plants were isolated by hydro-distillation for 2.5 $\mathrm{h}$ using Clevenger-type apparatus. Then essential oil content was quantified and stored at $4{ }^{\circ} \mathrm{C}$ in a sterilized vial until required. Also, essential oil yields as $\mathrm{kg} \mathrm{ha}^{-1}$ were measured by using following formula:

$$
\operatorname{EOY}\left(\mathrm{kg} \mathrm{ha}^{-1}\right)=\operatorname{EO}(\%) \times \operatorname{DW}\left(\mathrm{kg} \mathrm{ha}^{-1}\right)
$$

Were EOY is essential oil yield, EO is essential oil and DW is dry herb yield.

\section{STATISTICAL ANALYSIS}

Data were statically processed by analysis of variance (ANOVA) with using of SAS (Version 9.1) software, followed by the Duncan's multiple range comparisons test with a significance level of $p<0.05$.

\section{RESULTS AND DISCUSSION}

Data presented in Table II and III shows significant effects of irrigation intervals on proportion of leaf + flower and stem $(p<0.05)$ and other measured morphological traits $(p<0.01)$, while stems number and 1000 seed weight not influenced by irrigation intervals. Plant height, plant spread, stem diameter, leaf area, proportion of leaf + flower and stem, fresh and dry herb yield declined with increasing of irrigation intervals. In mentioned parameters, greatest values obtained under $\mathrm{IR}_{1}$ and the minimum values for these traits observed under $\mathrm{IR}_{2}$ or IR $\mathrm{IR}_{3}$ (Table II and III). Unlike mentioned traits, the highest value for proportion of stem (42.71\%) was obtained in $\mathrm{IR}_{3}$ treatment and reduced to 40.27 and $38.85 \%$ in $\mathrm{IR}_{2}$ and $\mathrm{IR}_{1}$, respectively. Of course, there was no significant difference between $\mathrm{IR}_{2}$ and $\mathrm{IR}_{1}$ treatments (Table III).

The reductions in plant height, leaf area, fresh and dry herb yield and other traits in higher irrigation intervals may be due to the decrease in the cell enlargement and more leaf senescence resulting from reduced turgor pressure (Shao et al. 2008, Farooq et al. 2009) or it may be due to a decrease in photosynthesis and alter canopy structure during the higher irrigation intervals (Shao et al. 2008). Also, Leithy et al. (2006) believed that, decrease in plant growth has been associated with lower photosynthesis rate due to declined stomatal conductance. Development of optimal leaf area is important for photosynthesis and production of dry herb yield (Jaleel et al. 2009), because when leaf area is lower, the capacity to light trap decreases and this led to reduction in photosynthesis rate (Khalid 2006). Furthermore, the effect of reduced irrigation on growth of plant may be due to the lower availability of sufficient moisture in rhizosphere and the lower absorption of nutrients (Singh et al. 1997). Indeed, in order to increase absorption of water, plants in water deficit conditions often reduce their biomass production and contribution more biomass to roots (Albouchi et al. 2003). Our results are in agreement with other reports which confirm the effect of irrigation on growth of medicinal and aromatic plants such as Lippia berlandieri (Vazquez and Dunford 2005), Hypericum brasiliense (Zobayed et al. 2007), Thymus transcapicus (Tabrizi et al. 2011) and Thymus daenansis (Bahreininejad 2013).

In other hand, ANOVA results indicated that the plant spread, stem diameter, leaf area and fresh herb yield were significantly affected by 
TABLE II

Effect of irrigation intervals, cattle manure levels and interaction of treatments on plant height, stems number, plant spread, stem diameter and leaf area in oregano.

\begin{tabular}{|c|c|c|c|c|c|c|}
\hline \multicolumn{2}{|c|}{ Treatments } & Plant height (cm) & Stems number & Plant spread (cm) & Stem diameter $(\mathrm{mm})$ & Leaf area $\left(\mathrm{cm}^{2}\right)$ \\
\hline \multicolumn{7}{|c|}{ Irrigation intervals } \\
\hline \multicolumn{2}{|l|}{$\mathrm{IR}_{1} \dagger$} & $33.92 \mathrm{a}$ & $13.37 \mathrm{a}$ & $36.11 \mathrm{a}$ & $2.23 \mathrm{a}$ & $919.93 \mathrm{a}$ \\
\hline \multicolumn{2}{|l|}{$\mathrm{IR}_{2}$} & $27.98 \mathrm{~b}$ & $11.37 \mathrm{a}$ & $29.33 b$ & $2.11 \mathrm{a}$ & $877.95 \mathrm{a}$ \\
\hline \multicolumn{2}{|l|}{$\mathrm{IR}_{3}$} & $28.03 \mathrm{~b}$ & $11.82 \mathrm{a}$ & $31.20 \mathrm{ab}$ & $1.50 \mathrm{~b}$ & $672.69 \mathrm{~b}$ \\
\hline \multicolumn{7}{|c|}{ Cattle manure } \\
\hline \multicolumn{2}{|l|}{$\mathrm{CM}_{0}$} & $28.56 \mathrm{~b}$ & $10.18 \mathrm{~b}$ & $27.08 \mathrm{~b}$ & $1.72 \mathrm{c}$ & $769.64 \mathrm{c}$ \\
\hline \multicolumn{2}{|l|}{$\mathrm{CM}_{10}$} & $29.22 \mathrm{ab}$ & $11.93 \mathrm{ab}$ & $33.07 \mathrm{a}$ & $1.92 \mathrm{~b}$ & $825.08 \mathrm{~b}$ \\
\hline \multicolumn{2}{|l|}{$\mathrm{CM}_{20}$} & $30.62 \mathrm{ab}$ & $13.67 \mathrm{a}$ & $35.11 \mathrm{a}$ & $2.04 \mathrm{a}$ & $841.31 \mathrm{~b}$ \\
\hline \multicolumn{2}{|l|}{$\begin{array}{l}\mathrm{CM}_{30} \\
\mathbf{I R} \times \mathbf{C M}\end{array}$} & $31.51 \mathrm{a}$ & $12.96 \mathrm{a}$ & $33.59 \mathrm{a}$ & $2.10 \mathrm{a}$ & $858.06 \mathrm{a}$ \\
\hline \multirow[t]{4}{*}{$\mathrm{IR}_{1}$} & $\mathrm{CM}_{0}$ & $30.20 \mathrm{~b}-\mathrm{d}$ & $10.47 \mathrm{bc}$ & $32.89 \mathrm{a}-\mathrm{c}$ & $1.99 \mathrm{~cd}$ & $897.40 \mathrm{a}$ \\
\hline & $\mathrm{CM}_{10}$ & $33.20 \mathrm{a}-\mathrm{c}$ & $13.53 \mathrm{a}-\mathrm{c}$ & $36.22 \mathrm{ab}$ & $2.12 \mathrm{bc}$ & $919.19 \mathrm{a}$ \\
\hline & $\mathrm{CM}_{20}$ & $35.27 \mathrm{ab}$ & $15.13 \mathrm{a}$ & $38.22 \mathrm{a}$ & $2.41 \mathrm{a}$ & $939.33 \mathrm{a}$ \\
\hline & $\mathrm{CM}_{30}$ & $37.00 \mathrm{a}$ & $14.33 \mathrm{ab}$ & $37.11 \mathrm{ab}$ & $2.39 \mathrm{a}$ & $923.80 \mathrm{a}$ \\
\hline \multirow[t]{4}{*}{$\mathrm{IR}_{2}$} & $\mathrm{CM}_{0}$ & $27.20 \mathrm{~d}$ & $9.40 \mathrm{c}$ & $20.78 \mathrm{~d}$ & $1.84 \mathrm{~d}$ & $774.47 \mathrm{~b}$ \\
\hline & $\mathrm{CM}_{10}$ & $25.67 \mathrm{~d}$ & $10.80 \mathrm{bc}$ & $25.78 \mathrm{~cd}$ & $2.11 \mathrm{bc}$ & $891.54 \mathrm{a}$ \\
\hline & $\mathrm{CM}_{20}$ & $28.53 \mathrm{~cd}$ & $13.07 \mathrm{a}-\mathrm{c}$ & $38.33 \mathrm{a}$ & $2.19 \mathrm{~b}$ & $908.50 \mathrm{a}$ \\
\hline & $\mathrm{CM}_{30}$ & $30.53 \mathrm{~b}-\mathrm{d}$ & $12.20 \mathrm{a}-\mathrm{c}$ & $32.44 \mathrm{a}-\mathrm{c}$ & $2.29 \mathrm{ab}$ & $937.30 \mathrm{a}$ \\
\hline \multirow[t]{4}{*}{$\mathrm{IR}_{3}$} & $\mathrm{CM}_{0}$ & $28.27 \mathrm{~cd}$ & $10.67 \mathrm{bc}$ & $27.56 \mathrm{~b}-\mathrm{d}$ & $1.34 \mathrm{f}$ & $637.07 \mathrm{~d}$ \\
\hline & $\mathrm{CM}_{10}$ & $28.80 \mathrm{~cd}$ & $11.47 \mathrm{a}-\mathrm{c}$ & $37.22 \mathrm{ab}$ & $1.53 \mathrm{e}$ & $664.51 \mathrm{~cd}$ \\
\hline & $\mathrm{CM}_{20}$ & $28.07 \mathrm{~cd}$ & $12.80 \mathrm{a}-\mathrm{c}$ & $28.78 \mathrm{a}-\mathrm{d}$ & $1.52 \mathrm{e}$ & $676.10 \mathrm{~cd}$ \\
\hline & $\mathrm{CM}_{30}$ & $27.00 \mathrm{~d}$ & $12.33 \mathrm{a}-\mathrm{c}$ & $31.22 \mathrm{a}-\mathrm{c}$ & $1.63 \mathrm{e}$ & $713.07 \mathrm{c}$ \\
\hline \multicolumn{7}{|l|}{ ANOVA } \\
\hline \multicolumn{2}{|l|}{ IR } & $* *$ & NS & $* *$ & $* *$ & $* *$ \\
\hline \multicolumn{2}{|l|}{$\mathrm{CM}$} & NS & $*$ & $* *$ & $* *$ & $* *$ \\
\hline \multicolumn{2}{|l|}{$\mathrm{IR} \times \mathrm{CM}$} & NS & NS & $*$ & NS & $* *$ \\
\hline
\end{tabular}

$\uparrow \mathrm{IR}=$ Irrigation intervals (weeks), $\mathrm{CM}=$ cattle manure levels $\left(\mathrm{t} \mathrm{ha}^{-1}\right)$.

In each section, means followed by the same letter within columns are not significantly different (p0.05) according to Duncan's multiple range test.

* Significant at the 0.05 level of probability, ** Significant at the 0.01 level of probability, NS: no significant.

TABLE III

Effect of irrigation intervals, cattle manure levels and interaction of treatments on proportion of stem and leaf + flower, fresh and dry herb yield in oregano.

\begin{tabular}{llllll}
\hline Treatments & $\begin{array}{l}\text { Stem } \\
\text { proportion (\%) }\end{array}$ & $\begin{array}{l}\text { Leaf + flower } \\
\text { proportion } \mathbf{( \% )}\end{array}$ & $\begin{array}{l}\text { Fresh herb yield } \\
\left.\mathbf{( k g ~ h a ~}^{-1}\right)\end{array}$ & $\begin{array}{l}\text { Dry herb yield } \\
\left(\mathbf{k g ~ h a}^{-1}\right)\end{array}$ & $\begin{array}{l}\mathbf{1 0 0 0} \text { seed } \\
\text { weight }(\mathbf{g})\end{array}$ \\
\hline Irrigation intervals & & & & & \\
$\mathrm{IR}_{1} \dagger$ & $38.85 \mathrm{~b}$ & $61.15 \mathrm{a}$ & $11704.6 \mathrm{a}$ & $3718.5 \mathrm{a}$ & $0.251 \mathrm{a}$ \\
$\mathrm{IR}_{2}$ & $40.27 \mathrm{~b}$ & $59.73 \mathrm{a}$ & $10067.4 \mathrm{~b}$ & $3026.5 \mathrm{~b}$ & $0.244 \mathrm{a}$ \\
$\mathrm{IR}_{3}$ & $42.71 \mathrm{a}$ & $57.29 \mathrm{~b}$ & $7951.2 \mathrm{c}$ & $2473.2 \mathrm{c}$ & $0.246 \mathrm{a}$ \\
$\mathrm{Cattle} \mathrm{manure}$ & & & & \\
$\mathrm{CM}_{0}$ & $41.15 \mathrm{a}$ & $58.85 \mathrm{a}$ & $9624.1 \mathrm{~b}$ & $3009.6 \mathrm{~b}$ & $0.245 \mathrm{a}$ \\
$\mathrm{CM}_{10}$ & $40.29 \mathrm{a}$ & $59.71 \mathrm{a}$ & $9795.6 \mathrm{~b}$ & $3037.1 \mathrm{~b}$ & $0.246 \mathrm{a}$ \\
$\mathrm{CM}_{20}$ & $39.55 \mathrm{a}$ & $60.45 \mathrm{a}$ & $10053.5 \mathrm{a}$ & $3097.7 \mathrm{ab}$ & $0.249 \mathrm{a}$ \\
$\mathrm{CM}_{30}$ & $41.44 \mathrm{a}$ & $58.56 \mathrm{a}$ & $10157.7 \mathrm{a}$ & $3146.5 \mathrm{a}$ & $0.251 \mathrm{a}$ \\
\hline
\end{tabular}


TABLE III (continuation)

\begin{tabular}{lllllll}
\hline Treatments & & $\begin{array}{l}\text { Stem } \\
\text { proportion (\%) }\end{array}$ & $\begin{array}{l}\text { Leaf + flower } \\
\text { proportion (\%) }\end{array}$ & $\begin{array}{l}\text { Fresh herb yield } \\
\left(\mathbf{k g ~ h a}^{-1}\right)\end{array}$ & $\begin{array}{l}\text { Dry herb yield } \\
\left(\mathbf{k g ~ h a}^{-1}\right)\end{array}$ & $\begin{array}{l}\mathbf{1 0 0 0} \text { seed } \\
\text { weight (g) }\end{array}$ \\
\hline $\mathbf{I R} \times \mathbf{C M}$ & & & & & & \\
$\mathrm{IR}_{1}$ & $\mathrm{CM}_{0}$ & $41.01 \mathrm{ab}$ & $58.99 \mathrm{ab}$ & $10144.4 \mathrm{a}$ & $3104.8 \mathrm{a}$ & $0.243 \mathrm{a}$ \\
& $\mathrm{CM}_{10}$ & $39.20 \mathrm{ab}$ & $60.80 \mathrm{ab}$ & $10132.0 \mathrm{a}$ & $3119.2 \mathrm{a}$ & $0.244 \mathrm{a}$ \\
& $\mathrm{CM}_{20}$ & $37.05 \mathrm{~b}$ & $62.95 \mathrm{a}$ & $9848.4 \mathrm{a}$ & $3023.6 \mathrm{a}$ & $0.243 \mathrm{a}$ \\
& $\mathrm{CM}_{30}$ & $38.13 \mathrm{ab}$ & $61.87 \mathrm{ab}$ & $9761.2 \mathrm{a}$ & $3032.8 \mathrm{a}$ & $0.253 \mathrm{a}$ \\
$\mathrm{IR}_{2}$ & $\mathrm{CM}_{0}$ & $40.27 \mathrm{ab}$ & $59.73 \mathrm{ab}$ & $9723.2 \mathrm{a}$ & $2992.0 \mathrm{a}$ & $0.250 \mathrm{a}$ \\
& $\mathrm{CM}_{10}$ & $38.28 \mathrm{ab}$ & $61.72 \mathrm{ab}$ & $9814.4 \mathrm{a}$ & $3021.2 \mathrm{a}$ & $0.251 \mathrm{a}$ \\
& $\mathrm{CM}_{20}$ & $40.31 \mathrm{ab}$ & $59.69 \mathrm{ab}$ & $9744.0 \mathrm{a}$ & $2994.0 \mathrm{a}$ & $0.253 \mathrm{a}$ \\
& $\mathrm{CM}_{30}$ & $42.21 \mathrm{ab}$ & $57.79 \mathrm{ab}$ & $9852.0 \mathrm{a}$ & $3039.2 \mathrm{a}$ & $0.253 \mathrm{a}$ \\
$\mathrm{IR}_{3}$ & $\mathrm{CM}_{0}$ & $42.18 \mathrm{ab}$ & $57.82 \mathrm{ab}$ & $9900.8 \mathrm{a}$ & $3124.4 \mathrm{a}$ & $0.243 \mathrm{a}$ \\
& $\mathrm{CM}_{10}$ & $43.40 \mathrm{a}$ & $56.60 \mathrm{~b}$ & $9932.4 \mathrm{a}$ & $3100.4 \mathrm{a}$ & $0.244 \mathrm{a}$ \\
& $\mathrm{CM}_{20}$ & $41.28 \mathrm{ab}$ & $58.72 \mathrm{ab}$ & $10076.0 \mathrm{a}$ & $3146.0 \mathrm{a}$ & $0.251 \mathrm{a}$ \\
& $\mathrm{CM}_{30}$ & $43.96 \mathrm{a}$ & $56.04 \mathrm{~b}$ & $9964.0 \mathrm{a}$ & $3175.2 \mathrm{a}$ & $0.247 \mathrm{a}$ \\
\hline $\mathbf{A N O V A}$ & & & & & \\
$\mathrm{IR}$ & & $*$ & $*$ & $* *$ & $\mathrm{NS}$ \\
$\mathrm{CM}$ & & $\mathrm{NS}$ & $\mathrm{NS}$ & $* *$ & $\mathrm{NS}$ & $\mathrm{NS}$ \\
$\mathrm{IR} \times \mathrm{CM}$ & & $\mathrm{NS}$ & $\mathrm{NS}$ & $\mathrm{NS}$ & $\mathrm{NS}$ & $\mathrm{NS}$ \\
\hline
\end{tabular}

$\dagger \mathrm{IR}=$ Irrigation intervals (weeks), $\mathrm{CM}=$ cattle manure levels $\left(\mathrm{t} \mathrm{ha}^{-1}\right)$.

In each section, means followed by the same letter within columns are not significantly different ( $p 0.05)$ according to Duncan's multiple range test.

* Significant at the 0.05 level of probability, ** Significant at the 0.01 level of probability, NS: no significant.

cattle manure levels $(p<0.01)$. Also, significant differences observed between cattle manure levels $(p<0.05)$ for stems number, while other measured traits (i.e. dry weight, proportion of leaf + flower and stem and 1000 seed weight) not influenced by cattle manure levels (Table II and III). Our results showed that values for stems number and plant spread increased by increasing of cattle manure levels from 0 to $20 \mathrm{t} \mathrm{ha}^{-1}$, while application of $30 \mathrm{t}$ $\mathrm{ha}^{-1}$ of cattle manure had a slight negative effect on these traits (Table II). On the other hand, increasing the amount of applied cattle manure levels from 0 to $30 \mathrm{t} \mathrm{ha}^{-1}$ showed a progressive effect on stem diameter, leaf area, fresh and dry herb yield (Table II and III). Addition of cattle manure to the soil increase water holding capacity, improve soil physical and chemical properties, create a good condition for biological process in rhizosphere and provide nutrient availability for plants (Arancon et al. 2004, Valiki et al. 2015). Our results are in agreement with previously published reports on Coriandrum sativum (Darzi 2012) and Salvia officinalis L. (Kaplan et al. 2009).

Also, plant spread and leaf area significantly influenced by interaction of treatments $(\mathrm{IR} \times \mathrm{CM})$ at $p<0.05$ and $p<0.01$, respectively. Although, interaction of treatments had no significant effects on other investigated morphological traits, seed yield and 1000 seed weight (Table II and III). Interaction of treatments did not show clear trend in plant spread (Table II). Higher values (38.33 and $38.22 \mathrm{~cm}$ ) for this parameter obtained in $\mathrm{IR}_{2}$ and $\mathrm{IR}_{1}$ with using $20 \mathrm{tha}^{-1}$ cattle manure, respectively. In this trait, lowest value $(20.78 \mathrm{~cm})$ observed in $\mathrm{IR}_{2}$ without utilization of cattle manure (Table II). The use of organic manure has been associated with higher plant available water, cation exchange capacity and lower bulk density as well as can 
increase beneficial micro-organisms (Drinkwater et al. 1995). Also, Arancon et al. (2004) reported that use of organic manures improve the growth rate in plant due to better availability of water and nutrient uptake that causes growth improvement.

For seed yield, ANOVA showed significant difference as effected by irrigation intervals $(p<0.05)$ (Figure 1), while this parameter not influenced by cattle manure levels and interaction of treatments (data not shown). The maximum and minimum values (14.6 and $12.64 \mathrm{~g} \mathrm{~m}^{-2}$ ) for seed yield obtained under lowest and highest irrigation intervals $\left(\mathrm{IR}_{1}\right.$ and $\left.\mathrm{IR}_{3}\right)$, respectively (Figure 1 ). Furthermore, 1000 seed weight not affected by irrigation intervals, cattle manure levels and interaction of treatments (Table III). Our results are consistent with research of Kim et al. (2007) who revealed that water stress did not affect the 1000 seed weight of sesame, showing that last responds to post flowering drought by reducing seed numbers, but not seed size.

\section{ESSENTIAL OIL CONTENT AND YIELD}

Interaction of irrigation intervals and cattle manure levels showed that essential oil ranged from 1.55 to $2.07 \%$ (Figure 2). The highest value for essential oil content of oregano obtained in $\mathrm{IR}_{3}$ with application of $30 \mathrm{t} \mathrm{ha}^{-1}$ cattle manure. In other hand, $\mathrm{IR}_{1}$ without use of cattle manure produce the lowest essential oil content (Figure 2). For essential oil yield, the lowest value $\left(46.37 \mathrm{~kg} \mathrm{ha}^{-1}\right)$ for essential oil yield was found in $\mathrm{IR}_{2}$ with application of $20 \mathrm{tha}^{-1}$ cattle manure. Unlike, the maximum mean value (66.62 $\mathrm{kg} \mathrm{ha}^{-1}$ ) for essential oil yield was resulted in IR 3 by use of $30 \mathrm{t} \mathrm{ha}^{-1}$ cattle manure (Figure 3). This result may be due to increase in essential oil content via a higher density of oil glands as a result of reduction in leaf area. Also, the effect of irrigation intervals on essential oil percentage may be due to its effect on enzyme activity and metabolism of essential oil production (Simon et al. 1992, Khalid et al. 2006). Water stress maybe increased essential oil content of more medicinal and aromatic plants because

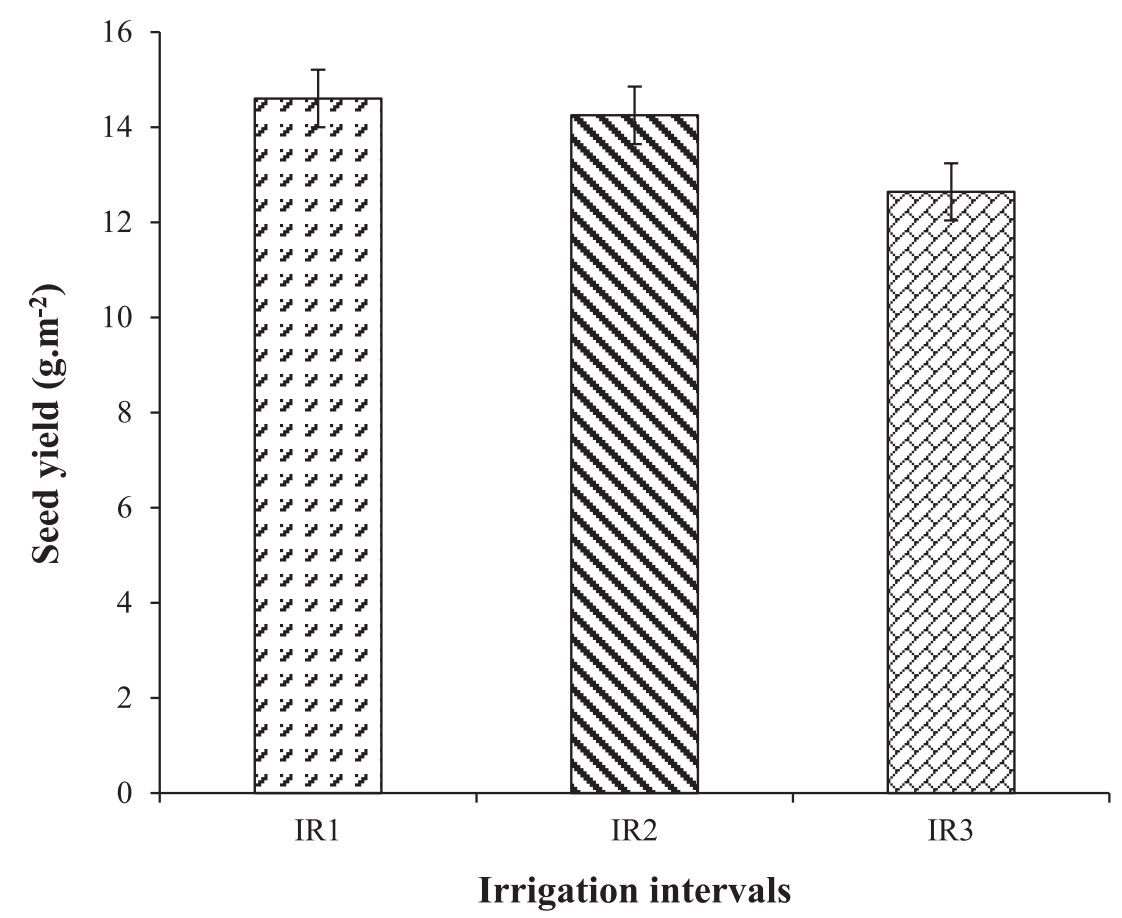

Figure 1 - Effect of irrigation intervals on seed yield of oregano. Vertical bars indicate standard errors. 


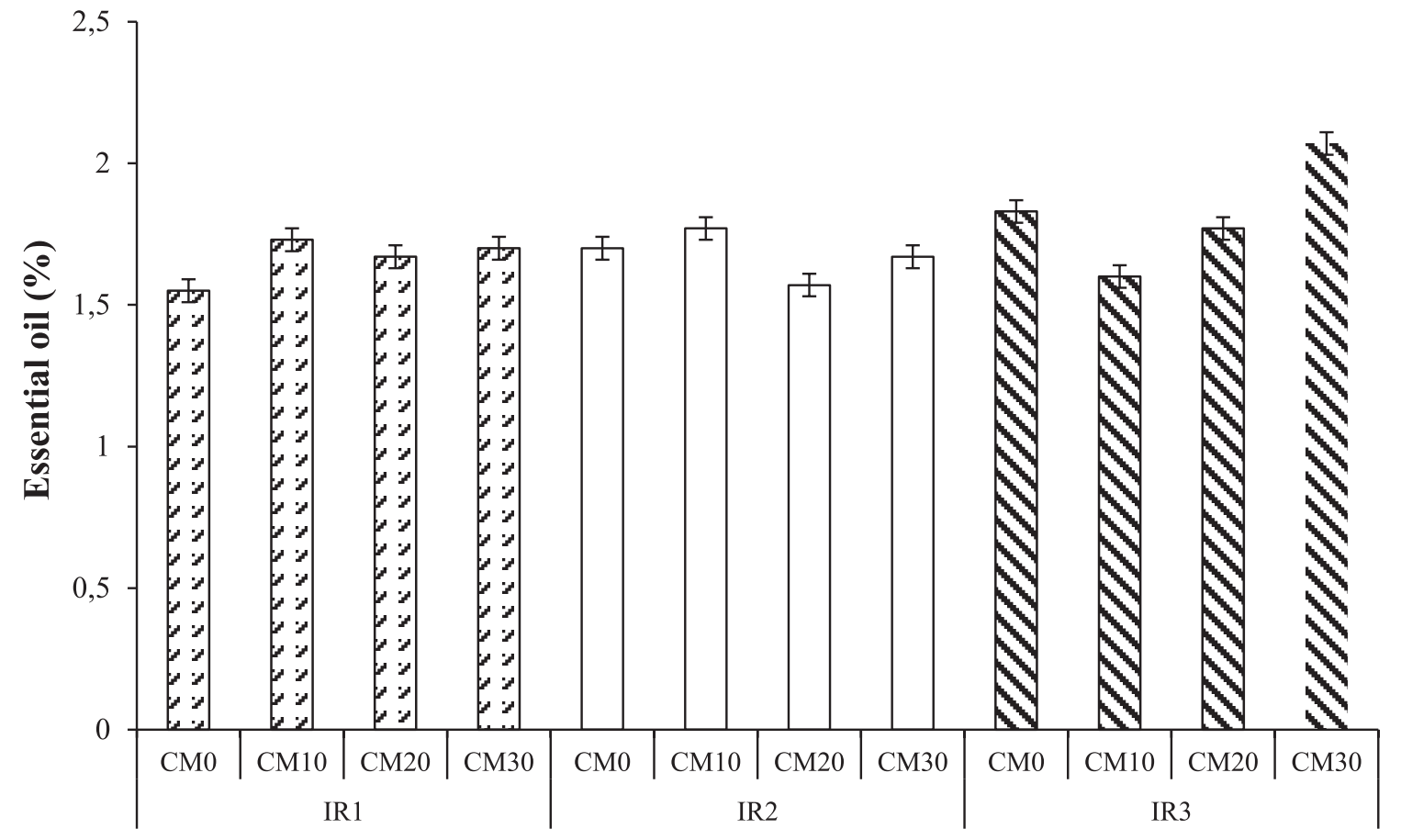

Interaction of treatments

Figure 2 - Effect of irrigation intervals (IR) and cattle manure levels (CM) on essential oil content (\%). vertical bars indicate standard errors.

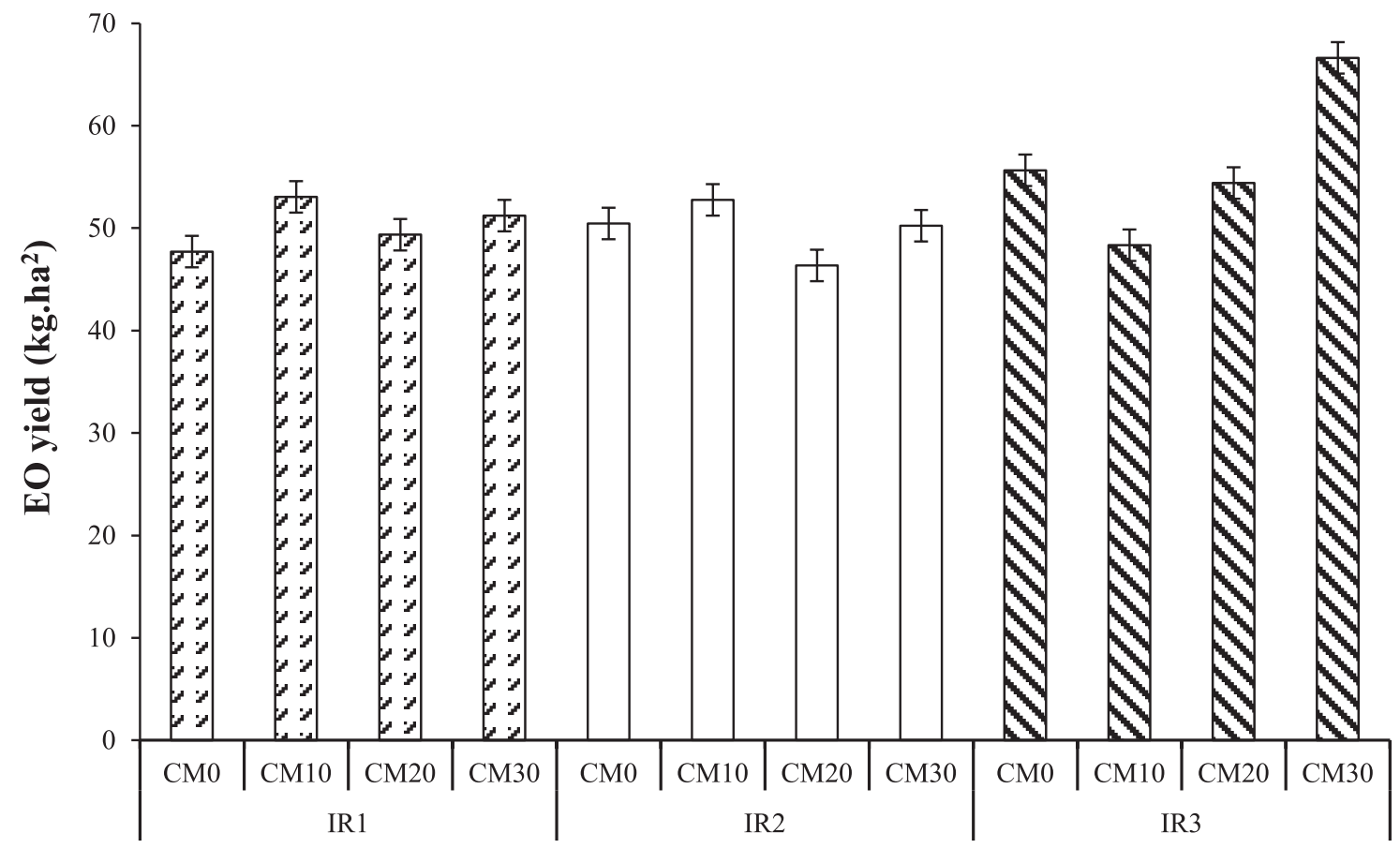

Interaction of treatments

Figure 3 - Effect of irrigation intervals (IR) and cattle manure levels on (CM) essential oil yield (kg ha $\left.{ }^{-1}\right)$. Vertical bars indicate standard errors. 
in case of stress, more metabolites are produced in the plant cells and substances prevented from oxidization in these stressed cells (Farahani et al. 2009). Moreover, Penka (1978) mentioned that essential oils are the product of the respiratory catabolic processes which increase under water deficit. In agreement with our results, Baher et al. (2002) showed that essential oil percentage of Satureja hortensis increased under water deficit.

Also, the useful effect of cattle manure levels on essential oil percentage may be due to the influence of organic manure on accelerating metabolism reaction as well as stimulating enzymatic systems response for biosynthesis of essential oil content (Khalid and Hossein 2012). These results are contrast with those reported by Ram et al. (2006) and Tabrizi et al. (2011). Also, our results are in agreement with those reported on other plants such as Pimpinella anisum L. (Zehtab-Salmasi et al. 2001), Petroelinum crispum (Petropoulos et al. 2008), Carum carvi L. (Laribi et al. 2009) and Apium graveolense L. (Khalid and Hossein 2012).

\section{CONCLUSIONS}

The present study indicates that increasing of irrigation intervals have negative effect on morphological traits while, it not significant effect on essential oil content and yield. On the other hand, utilization of organic manure had positive effects on some parameters such as leaf area, fresh and dry herb yield, stems number, plant spread and stem diameter. In general, it seems that cultivation of oregano with 3 weeks irrigation intervals by use of $30 \mathrm{t} \mathrm{ha}^{-1}$ cattle manure is a good practice for achieving high essential oil content and yield in this region.

\section{REFERENCES}

ADAMS K, SIVROPOULOU A, KOKKINI LT AND ARSENALIS M. 1998. Antifungal activities of Origanum vulgare subsp. Hirtum, Mentha spicata, Lavandula angustifolia and salvia fruticosa essential oils against human pathogenic fungi. J Agr Food Chem 46: 1739-1745.

ALBOUCHI A, BEJAOUI Z AND EL-AOUNI MH. 2003. Influence of moderate or severe water stress on the growth of Casuarina glauca Sieb. Seedlings. Secheresse 14: 137142.

ALIGIANIS N, KALPOUTZAKIS E, MITAKU S AND CHINOU IB. 2001. Composition and antimicrobial activity of the essential oil from Origanum species. J Agr Food Chem 49: 4168-4170.

ARANCON NQ, EDWARDS CA, BIERMAN P, WELCH C AND METZGER JD. 2004. Influences of vermicomposts on field strawberries: 1. Effects on growth and yields. Bioresource Technol 93: 145-153.

BAECK H, KUENWOO P, BAECK HW AND PARK KW. 2001. Effect of watering on growth and oil content of sweet basil (Ocimum americanum L.). Korean J Hort Sci Tech 19: 81-86.

BAHER ZF, MIRZA M, GHORBANLI M AND REZAII MB. 2002. The influence of water stress on plant height, herbal and essential oil yield and composition in Satureja hortensis L. Flavour Fragr J 17: 275-277.

BAHREININEJAD B, RAZMJOO J AND MIRZA M. 2013. Influence of water stress on morpho-physiological and phytochemical traits in Thymus daenensis. Int J Plant Prod 7: 151-166.

BAJELI J, TRIPATHI S, KUMAR A, TRIPATHI A AND UPADHYAY RK. 2016. Organic manures a convincing source for quality production of Japanese mint (Mentha arvensis L.). Ind Crop Prod 83: 603-606.

BANNAYAN M, NADJAFI F, AZIZI M, TABRIZI L AND RASTGOO M. 2008. Yield and seed quality of Plantago ovata and Nigella sativa under different irrigation treatments. Ind Crop Prod 27: 11-16.

BETTAIEB I, ZAKHAMA N, WANNES WA, KCHOUK ME AND MARZOUK B. 2009. Water deficit effects on Salvia officinalis fatty acids and essential oils composition. Sci Hort 120: 271-275.

DARZI MT. 2012. Effects of organic manure and biofertilizer application on flowering and some yield traits of coriander (Coriandrum sativum). Intl J Agri Crop Sci 4: 103-107.

DELFINE S, LORETO F, PINELLI P, TOGNETTI R AND ALVINO A. 2005. Isoprenoids content and photosynthetic limitations in rosemary and spearmint plants under water stress. Agric. Ecosyst. Environ. 106: 243-252.

DRINKWATER LE, LETOURNEAU DK, WORKNEH F, VAN BRUGGEN AHC AND SHENNAN C. 1995. Fundamental differences between conventional and organic tomato agroecosystems in California. Ecol Appl 1: 1098-1112.

FARAHANI HA, VALADABADI SA, DANESHIAN J, SHIRANIRAD AH AND KHALVATI MA. 2009. Medicinal and aromatic plants farming under drought conditions. J Hortic For 1: 86-92. 
FAROOQ M, WAHID A, KOBAYASHI N, FUJITA D AND BASRA SMA. 2009. Plant drought stress: effects, mechanisms and management. Agron Sustain Dev 29: $185-212$.

GHOLIZADEH A, AMIN MSM, ANUAR AR, ESFAHANI M AND SABERIOON MM. 2010. The study on the effect of different levels of zeolit and water stress on growth, development and essential oil content of moldavian balm (Dracocephalum moldavica L.). Am J Appl Sci 7: 33-37.

HASSANI A. 2006. Effect of water deficit stress on growth, yield and essential oil content of Dracocephalum moldavica. Iran J Med Arom Plants 22: 256-261. (In Persian).

HECL J AND SUSTRIKOVAA. 2006. Determination of heavy metals in chamomile flower drug-an assurance of quality control. In International Symposium on Chamomile Research, Development and Production. Presov, Slovakia, p. 69.

HOAREAU L AND DA SILVA EJ. 1999. Medicinal plants: a re-emerging health aid. Electron J Biotechnol 2: 3-4.

JALEEL CA, MANIVANNAN P, WAHID A, FAROOQ M, AL-JUBURI HJ, SOMASUNDARAM R AND PANNEERSELVAM R. 2009. Drought stress in plants: a review on morphological characteristics and pigments composition. Int J Agric Biol 11(1): 100-105.

JONES HG AND TARDIEN F. 1998. Modelling water relations of horticultural crops: a review. Sci Hort 74: 2146.

KAPLAN M, KOCABAS I, SONMEZ I AND KALKAN H. 2009. The effects of different organic manure applications on the dry weight and the essential oil quantity of sage (Salvia fruticosa Mill.). Acta Hortic 826: 147-152.

KHALID KA. 2006. Influence of water stress on growth, essential oil, and chemical composition of herbs (Ocimum sp.). Int Agrophys 20: 289-296.

KHALID KA AND HUSSEIN MS. 2012. Effect of cattle and liquid manures on essential oil and antioxidant activities of celery (Apium graveolens L.) Fruits. J Essent Oil-Bear Plants 15: 97-107.

KIM KS, PARK SH AND JENKS MA. 2007. Changes in leaf cuticular waxes of sesame (Sesamum indicum L.) plants exposed to water deficit. J Plant Physiol 164: 1134-1143.

LARIBI B, BETTAIEB I, KOUKI K, SAHLI A, MOUGOU A AND MARZOUK B. 2009. Water deficit effects on caraway (Carum carvi L.) growth, essential oil and fatty acid composition. Ind Crop Prod 30: 372-379.

LEITHY S, EL-MESEIRY TA AND ABDALLAH EF. 2006. Effect of biofertilizer, cell stabilizer and irrigation regime on rosemary herbage oil quality. J Appl Sci 2: 773-779.

LEU A. 2007. Organics and soil carbon: Increasing soil carbon, crop productivity and farm profitability. In Managing the Carbon Cycle, Katanning, Western Australia, Workshop, p. 19-26.
LIANG CH, CHOU TH AND DING HY. 2010. Inhibition of melanogensis by a novel origanoside from Origanum vulgare. J Dermatol Sci 57: 170-177.

OZGUVEN M, MUZAFFER K, SENER B, ORHAN I, SEEROGLU N, KARTAL M AND KAYA Z. 2008. Effects of varying nitrogen doses on yield, yield components and artemisinin content of Artemissia annua L. Ind Crop Prod 27: $60-64$.

PENKA M. 1978. Influence of irrigation on the contents of effective substances in officinal plants. Act Hort 73: 181197.

PETROPOULOS SA, DAFERERA D, POLISSIOU MG AND PASSAM HC. 2008. The effect of water deficit stress on the growth, yield and composition of essential oils of parsley. Sci Hort 115: 393-397.

RAM D, RAM M AND SINGH R. 2006. Optimization of water and nitrogen application to menthol mint (Mentha arvensis L.) through sugarcane trash mulch in a sandy loam soil of semi-arid subtropical climate. Bioresource Technol 97: 886-893.

RAM M AND KUMAR S. 1997. Yield improvement in the regenerated and transplanted Mint (Mentha arvensis) by recycling the organic wastes and manures. Bioresource Technol 59: 141-149.

RAO BR. 2001. Biomass and essential oil yields of rainfed palmarosa (Cymbopogonmartinii (Roxb.) Wats. var. motia Burk.) supplied with different levels of organic manure and fertilizer nitrogen in semi-arid tropical climate. Ind Crop Prod 14: 171-178.

RAUT JS AND KARUPPAYIL SM. 2014. A status review on the medicinal properties of essential oils. Ind Crop Prod 62: 250-264.

SANTOS MF, MENDONÇA MC, CARVALHO FILHO JLS, DANTAS IB, SILVA-MANN R AND BLANK AF. 2009. Cattle manure and biofertilizer on the cultivation of lemon balm (Melissa officinalis L.). Rev Bras Plant Med 11: 355 359.

SCHROTH G AND SINCLAIR FL. 2003. Trees, crops, and soil fertility: concepts and research methods. CABI Publishing, Wallingford, $437 \mathrm{p}$.

SHAO HB, CHU LY, JALEEL CA AND ZHAO CX. 2008. Water-deficit stress-induced anatomical changes in higher plants. Comptes Rendus Biol 331: 215-225.

SIMON JE, REISS-BUHENHEINRA D, JOLY RJ AND CHARLES DJ. 1992. Water stress induced alterations in essential oil content and composition of sweet basil. J Essent Oil Res 4: 71-75.

SINGH M, GANESHA-RAO RS AND RAMESH S. 1997. Irrigation and nitrogen requirement of lemongrass (Cymbopogon flexuosus (Sleud) Wats) on a red sandy loam soil under semiarid tropical conditions. J Essent Oil Res 9: 569-574.

SNOGERUP S. 1971. Evolutionary and plant geographical aspects of Chasmophytic communities. In: Davis PH, 
Harper PC and Hedge IC (Eds), Plant life of South-West Asia, p. 157-170. -Edinburgh, the Botanical Society.

SPADA P AND PERRINO P. 1996. Conservation of Oregano species in national and international collections: an assessment. In Oregano, proceedings of the IPGRI International workshop on Oregano, 1996, p. 8-12.

TABRIZI L, KOOCHEKI A, MOGHADDAM PR, MAHALLATI MN AND BANNAYAN M. 2011. Effect of irrigation and organic manure on Khorasan thyme (Thymus transcaspicus Klokov). Arch Agron Soil Sci 57: 317-326.

TEZARA W, MITCHELL VJ, DRISCOLL SD AND LAWLOR DW. 1999. Water stress inhibits plant photosynthesis by decreasing coupling factor and ATP. Nature 401: 914-917.

TUCKER AO AND MACIARELLO MJ. 1994. Oregano: botany, chemistry, and cultivation. In: Charalambous $\mathrm{G}$ (Ed), Spices, herbs and edible fungi. Elsevier Science B.V., Oxford, UK, p. 439-456.

UCAN K, KILLI F, GENCOGLAN C AND MERDUN H. 2007. Effect of irrigation frequency and amount onwater use efficiency and yield of sesame (Sesamum indicum L.) under field conditions. Field Crops Res 101: 249-258.

VALIKI SRH, GHANBARI S, AKBARZADEH M, ALAMDARI MG AND GOLMOHAMMADZADEH S.
2015. Effect of organic and chemical fertilizers on dry yield, essential oil and compounds on rosemary (Rosemarinus officinalis L.). Biol Forum - Int J 7: 773-782.

VAZQUEZ RS AND DUNFORD NT. 2005. Bioactive components of Mexican oregano oil as affected by moisture and plant maturity. J Essent Oil Res 17: 668-671.

VOKOU D, KOKKINI S AND BESSIERE JM. 1993. Geographic variation of Greek oregano (Origanum vulgare ssp. hirtum) essential oils. Biochem Syst Ecol 21: 287-295. WANG WX, VINOCUR B, SHOSEYOV O AND ALTMAN A. 2001 Biotechnology of plant osmotic stress tolerance: physiological and molecular considerations. Acta Hort 560: 285-292.

ZEHTAB-SALMASI S, JAVANSHIR A, OMIDBAIGI R, ALYARI H AND GHASSEMI-GOLEZANI K. 2001. Effects of water supply and sowing date on performance and essential oil production of anise (Pimpinella anisum L.). Acta Agron Hung 49: 75-81.

ZOBAYED SMA, AFREEN F AND KOZAI T. 2007. Phytochemical and physiological changes in the leaves of St. John's wort plants under a water stress condition. Environ Exp Bot 59: 109-116. 